\title{
Richard Sennett: Building and dwelling: ethics for the city
}

\author{
Penguin Books, 2019, 368 pp., ISBN: 9780141022116
}

\section{Yona Ginsberg ${ }^{1}$}

Published online: 26 June 2020

(c) Springer Nature B.V. 2020

This book is about how cities are built and how people live in them. Sennett distinguishes between two aspects of the city, the ville and the cite'. The ville refers to the built urban environment, while the cite' deals with the way of life, the attitude to neighbors and strangers. The ville deals with the total city, while the cite' means a specific place in the urban environment.

This is a very rich manuscript which analyzes cities on a long historic spectrum, from ancient Athens to modern global cities both in the West such as London, Paris and New York, and cities in developed countries like Delhi and Changhei. Sennett presents a very impressive literature survey and quotes among others planners like Jane Jacobs and Mumford and discusses the differences between them. Both were concerned with the relative balance between the built and the lived (p.79). In contrast to Mumford, Jacobs advocates slow growth, mixed neighborhoods, street life and social control. Sennett also relies on philosophers like Kant and Walter Benjamin.

In addition to the long literature survey, Sennett relies on his own rich experience as a planner in various cities around the globe, as well as a theorist of urban studies. Various parts of the book are based on participant observations in his own London neighborhood, in the market of Nehru place in Delhi and on Kantstrasse in Berlin.

The book consists four parts. The first part describes the professional urbanism, i.e. city making has started and how this practice has changed over time. Up to the nineteenth century, city planning tried to connect the lived and the built, the ville and cite'. Sennett presents various examples such as the Haussman Boulevards in Paris. In the twentieth century, those two went apart. Planners constructed the ville without taking into consideration the way people live, i.e. cite'. Some even attempted to change the behavior of residence through their buildings, but did not succeed.

On the other hand, the author criticizes the Chicago School for concentrating on the way people live in cities but ignoring how cities are built. Sennett discusses his own personal experience as a planner to adjust physical plans to people's needs and wishes, an effort which sometimes failed. As a sociologist working for several master plans, I can sympathize with his disappointments.

Yona Ginsberg

ginsby@biu.ac.il

1 Department of Sociology, Bar-Ilan University, Ramat-Gan, Israel 
In the second part, Sennett analyzes how cities are affected by the division between the built and the lived. He points out the big expansion of cities in the Global South which adapted the same problems and conflicts of the Global North and are unable to cope with them. For example, the difficulty of Mr. Sudhir, his Delhi informant, to find a dwelling unit in the "informal city".

In the third part, the author presents what the city could be like if it would be more open. Much of the book is devoted to the distinction between closed and open forms of cities. In an open form enables simultaneous activities. The open city prefers the border over the boundary, which means that the city is flexible and changes could be made over time. The city is heterogeneous and allows different functions to develop in the same area. Sennett argues that closed cities are homogeneous and presents the "gated communities" as an example of the closed city. He thinks this kind of housing should not be built.

An open system requires people to cope with complexity and changes. The open system "marks the city in modest ways, using simple materials" (p.140). The city gets a complex image, and buildings are in a way incomplete so that that changes can be made. There are open spaces which are connected to the buildings. Residents live on dense streets and meet on parks and other public spaces. "An open ville will avoid committing the sins of repetition and static form; it will create the material conditions in which people might thicken and deepen their experience of collective life" (p. 141).

The final chapter - the crookedness of the city - deals with natural disasters which are a threat to the city and might destroy the relation between the built and the lived. Sennett mentions among others, hurricane Sandy, climate change and pollution which are a danger to the city. He also suggests how to deal with those disasters.

Since this review is written in the midst of Covid 19, i.e. the Corona virus crises, one cannot ignore the impact of an epidemics on the city. We are aware how cities all over the world are affected by this plague. The impact on the way of life i.e. the cite' is traumatic. Since there is no cure to the disease, one way to avoid getting sick is keeping "social distance" from each other. This of course effects the behavior in public places.

How should social life be carried out in the city? In his very vivid description of Kantstrasse in Berlin, Sennett answers this question. He does not advocate the need for intimate social ties in order to be part of the community. He quotes Kant's "Unsocial sociability" (p. 295), which means that people tolerate different others. Identification should not rule the cite' and people should become "indifference to difference"(p. 299). Kantstrasse residents do not need to get involved as long as they do not have to act together and this is the way it should be. Sennett describes this type of relation in the way Simmel described urban life, with the blasé attitude.

Sennett concludes by saying "The ethical connection between urbanist and urbanite lie in practicing a certain kind of modesty: living one among many, engaged by a world which does not mirror oneself" (p. 302). This is a lesson that should be learned by those who are involved with creating better living in cities.

This is a very interesting book. It deals with urbanism from various aspects. It is rich, but sometimes too detailed and therefore hard to follow. I am not sure that intimate social ties do not contribute to urban life, as appears in this book. It seems one should not ignore social networks.

Publisher's Note Springer Nature remains neutral with regard to jurisdictional claims in published maps and institutional affiliations. 